\title{
EWOLUCJA SZWEDZKIEGO MODELU GOSPODARKI
}

\author{
I. WPROWADZENIE: \\ O KŁOPOTACH Z DYSKUSJA O MODELU SZWEDZKIM \\ (CZY TEŻ RACZEJ O MODELACH)
}

Dyskusja na temat modelu szwedzkiego, o ile w ogóle do niej dochodzi, powoduje rozmaite kłopoty, które warto zasygnalizować już na początku powziętej przeze mnie analizy. Otóż charakteryzuje się ona dwiema cechami, które znacznie utrudniają dyskurs. Pierwsza jej cecha to emocjonalizm, a druga to raczej niewielki zakres wiedzy wykazywany przez dyskutantów.

Warto zwrócić uwagę na emocje, jakie wywołuje u zwolenników rozwiązań kolektywistycznych krytyczna analiza szwedzkiej gospodarki. Intelektualne fascynacje kolektywistycznymi rozwiązaniami ponosiły bowiem od lat 80 . XX w. klęskę za klęska. Najpierw Chiny komunistyczne porzuciły komunistyczny ekstremizm, gdy ówczesny przywódca Deng Tsiaoping stwierdził, że „nieważne jest, czy kot jest czarny, czy biały; ważne, czy dobrze łowi myszy”. I Chiny z sukcesem - na razie przynajmniej - połączyły komunistyczną dyktaturę z kapitalistycznym rynkiem ${ }^{1}$. Dalej, komunizm typu sowieckiego upadł pod ciężarem własnej nieudolności. Fascynujący niegdyś rozmaite odcienie lewackich intelektualistów model kubański wydaje się dogorywać wraz ze swoim przywódca.

Jeśli więc chce się zachować wiarę w jakąś socjalistyczną drogę społeczno-ekonomicznego postępu, to pozostał już wierzącym w nią socjalistom tylko model szwedzki. Bo europejski model socjalny przeżywa od lat zauważalne przez wszystkich - rosnące kłopoty. W rezultacie jeśli chcemy analitycznie zbadać gospodarkę szwedzka, porównując koncepcje modelowe z rzeczywistością ekonomiczną, to wywołuje to emocje wynikające ze zderzenia wiedzy $\mathrm{z}$ wiarą.

Następny, nieco wstydliwy, problem wynika z niewielkiej wiedzy, jaką wykazuja od wielu lat zwolennicy modelu szwedzkiego. Obrońcy szwedzkiego modelu nie zauważaja problemów, z którymi gospodarka szwedzka boryka się od kilku dziesięcioleci. Gorzej, często nie zauważają oni, że model szwedzki, do którego się odwołuja, nie istnieje. Że od wczesnych lat 90 . XX w. do

${ }^{1}$ Zob. jednak J. Winiecki, The BRIC Group - How Strong a Challenge to the West?, ,World Economics" 13, 2012, nr 2. Wskazuję tam, że taka symbioza jest możliwa na etapie pierwszej transformacji strukturalnej (industrializacji), ale już raczej nie na etapie drugiej transformacji strukturalnej: przesunięcia się punktu ciężkości gospodarki z sektora przemysłu do sektora usług o wysokim nasyceniu kapitałem ludzkim. 
ostatnich lat przed obecnym kryzysem finansowym (nazwijmy go po imieniu: kryzysem Zachodu ${ }^{2}$ ) mieliśmy do czynienia $\mathrm{z}$ radykalnie zmodyfikowanym modelem szwedzkim. Nazwałbym go, używając informatycznej terminologii, modelem 2.0, a obecnie dokonują się - pod presją rzeczywistości - w tymże modelu 2.0 kolejne, daleko idące zmiany.

Uzasadnione wydaje się więc pytanie o przysłowiowa zawartość cukru w cukrze, czyli warto również pokusić się o odpowiedź na pytanie, ile oryginalnego modelu szwedzkiego (modelu 1.0) znajdujemy $\mathrm{w}$ obecnym, ewoluującym modelu szwedzkim. W niniejszym artykule spróbuję nie tylko dokonać konfrontacji modeli z rzeczywistością gospodarczą i wskazać, w jakim stopniu owe modele poprawiły wskaźniki ekonomiczne gospodarki szwedzkiej, lecz także zajmę się pomijaną w analizach genezą modelu szwedzkiego, jego kolejnymi modyfikacjami i - co równie ważne - kierunkiem tychże modyfikacji.

\section{PREHISTORIA MODELU SZWEDZKIEGO}

Oryginalny model szwedzki narodził się na przełomie lat 20. i 30. XX w. i był niewatpliwym dzieckiem szwedzkiej socjaldemokracji. Był też bez wątpienia projektem ideologicznym, tak jak model komunistyczny. Choć obydwa należą do kategorii modeli kolektywistycznych, model szwedzki był zdecydowanie od tego ostatniego różny. Różnice konstrukcyjne sa, rzecz oczywista, najbardziej widoczne. Model komunistyczny zakładał, jak wiadomo, nacjonalizacje sfery produkcyjnej, natomiast oryginalny model szwedzki zakładał daleko idąca nacjonalizację sfery dochodowej. Kompromis ideologiczny szwedzkiej socjaldemokracji ukształtował się już w latach 20. XX w. I zakładał, że efektywność szwedzkich właścicieli i menedżerów warta jest utrzymania, natomiast przemiany społeczne socjaldemokracja realizować będzie głównie, nacjonalizując, via podatki, część zysków właścicieli firm. Dodajmy, że część ta rosła od lat 30 . do lat 80 . XX w. Po stosunkowo krótkim okresie okazało się, że zyski nie wystarczaja do realizacji coraz bardziej ambitnych zamierzeń, i zaczęła się też nacjonalizacja dochodów osób zatrudnionych.

Jeśli istniało coś wspólnego między obydwoma modelami, to była to wiara $\mathrm{w}$ planowanie jako metodę przekształcania gospodarki i społeczeństwa. Ideolodzy socjaldemokracji, Gunnar i Alva Myrdalowie, wytyczali tę drogę już w swojej książce z 1934 r.: „Najważniejszym zadaniem polityki społecznej jest [...] organizacja i sterowanie narodowa konsumpcja (sic!) według innych reguł niż tak zwany wolny wybór w konsumpcji [...]. W przyszłości nie będzie społecznie obojętne, co ludzie robią ze swoimi pieniędzmi: jakie standardy mieszkaniowe utrzymuja, jaką żywność i odzież kupują [...]. Przyszłe trendy faworyzują społeczno-polityczną organizację i kontrolę nie tylko podziału dochodów [...]" ${ }^{3}$. Na marginesie: to właśnie przed takimi demokratycznymi

\footnotetext{
${ }^{2}$ Zob. J. Winiecki, Kryzys strefy euro i jego źródta w funkcjonowaniu państwa opiekuńczego, „Ruch Prawniczy, Ekonomiczny i Socjologiczny" 74, 2012, z. 1.

${ }^{3}$ A. Myrdal, G. Myrdal, Kris i befolkningsfragan, Stockholm 1934, cyt. za: M. Rojas, Sweden after the Swedish Model. From Tutorial State to Enabling State, Timbro, Stockholm 2005.
} 
socjalistami przestrzegał w swojej książce z 1945 r.: Droga do poddaństwa (Road to Serfdom) Friedrich von Hayek!

Znacznie większe są różnice fundamentów ideologicznych. Utopia marksowska zakładała uniwersalność swoich recept. Socjalizm Marksa był - jak twierdził tenże - „naukowy”, a więc aplikowalny w każdym kraju, w którym postępuje industrializacja. Szwedzcy lewicujący ideolodzy (politycy, dziennikarze, rzadziej naukowcy) do początku lat 90 . XX w. chętnie chwalili się szwedzkim modelem i przedstawiali go jako przykład do naśladowania. Niemniej sami w niewielkim stopniu zdawali sobie sprawę, jak dalece szwedzka utopia jest zakotwiczona w szwedzkich instytucjach i szwedzkiej historii.

Po pierwsze, model szwedzki miał silne wsparcie w pozycji niezależnych rolników i ich relacji z władzą królewską. Szwecja nie miała ani silnej arystokracji i ziemiaństwa, ani silnego mieszczaństwa. Za to już od XIV w. niezależni rolnicy mieli swoją stanową reprezentację $\mathrm{w}$ parlamencie; obok tradycyjnych stanów reprezentowana też była $\mathrm{w}$ nim warstwa chłopska ${ }^{4}$. W Anglii po trwającym przez ponad pół wieku konflikcie powstała w końcu XVII w. koncepcja: „,król w parlamencie”; król panuje, ale nie rządzi. W Szwecji pojawiła się cztery wieki wcześniej koncepcja, którą nazwałbym: „król, który (inaczej niż w Anglii) rządzi, ale swoje rządy opiera na systemie konsultacji: od gminnych do parlamentu (Riksdag), oraz na poparciu niezależnych rolników".

Stąd w Szwecji istniała tradycja silnej władzy centralnej i słabego parlamentu. Niewiele zmieniły tutaj liberalne prądy Oświecenia. Poniższy przykład wart jest przedstawienia. Szwecja była pierwszym krajem w Europie, w którym pojawił się pieniądz papierowy. Najpierw jako IOU (najwcześniejsza wersja weksla), a potem jako pieniądz drukowany przez bank centralny Szwecji (Riksbank). Nadmiar pieniądza drukowanego przez rządzące stronnictwo mieszczańskie, zwane „,rządem kapeluszy” (od miejskiego nakrycia głowy), spowodował - jak można się było spodziewać - inflację. Zrujnowała ona wielu rolników i posiadaczy oszczędności. Stronnictwo mieszczańskie przegrało wybory i do władzy doszło stronnictwo agrariuszy, zwane „rządem czapek” (ditto), które zwalczało inflację, ograniczając silnie podaż pieniądza. Tym razem efektem - spodziewanym przez ekonomistów - był spadek produkcji i cen. „Kapelusze” doszły ponownie do władzy, ale na krótko.

W 1772 r. król Gustaw III dokonał zamachu stanu, objął pełnię władzy i wprowadził kruszcowy pieniądz srebrny. Jak napisali autorzy, za którymi przytaczam tę informację: ,inflacja okazała się rujnująca dla demokracji”. W gruncie rzeczy nastapił powrót do sojuszu tronu i niezależnych rolników. Instytucje państwa, coraz bardziej niezbędne w świecie nadchodzącej rewolucji przemysłowej, powstawały odgórnie, bez walk i kompromisów z warstwa mieszczańską i jeszcze mniej liczną arystokracją i ziemiaństwem. Rozbudowujący się aparat państwowy wchłonął zresztą znaczną część warstw wyższych, pozbawiając ją materialnych podstaw niezależności.

Powstało w ten sposób, ewolucyjnie, państwo narodowe; tym łatwiej że jednorodne etnicznie i religijnie. Warstwy uprzywilejowane traciły stopniowo

\footnotetext{
${ }^{4}$ Za: M. Rojas, op. cit., s.8 i n.

${ }^{5}$ M. Szaleniec, W. Majerkiewicz, Historia inflacji (cz. III), NBPortal, 6 maja 2008 r.
} 
swoje przywileje, i to na długo przed zwycięstwami parlamentarnymi socjaldemokracji. Szwedzka kultura polityczna oparta była na podziale władzy między różnymi szczeblami samorządowymi i na tradycji politycznego aktywizmu większości społeczeństwa, czyli rolników. Jak to obrazowo określił historyk Lars Tragardh, tak kształtowały się te relacje do czasu, gdy „ruch robotniczy i socjaldemokracja stały się zdolne do wzięcia na swoje barki tego podwójnego dziedzictwa i przejęcia go odgórnie, w formie partii politycznej, i oddolnie, w formie ruchu ludowego" ${ }^{6}$.

\section{MODEL SZWEDZKI 1.0: SOCJALDEMOKRATYCZNY FOLKHEMMET, CZYLI SYMBIOZA PAŃSTWA SOCJALNEGO I PAŃSTWA NIAŃKI}

Kapitalistyczna rewolucja przemysłowa przyszła do Szwecji raczej późno. Liberalizacja gospodarki następowała stopniowo: od lat 30. do 60. XIX w. Wolność handlu i przedsiębiorczości miała swoją kulminację w regulacjach, a raczej deregulacjach powziętych w 1864 r. Wspierały ją też instytucje tworzone przez państwo. Obok tradycyjnej w kontynentalnej Europie roli państwa w budowie infrastruktury technicznej, władze szwedzkie - biorąc za wzór Niemcy - stworzyły sieć szkół technicznych, które dostarczyły wykwalifikowanych kadr dla przemysłu ciężkiego.

Rozwój przemysłu ciężkiego nastąpił zreszta w Szwecji wcześniej, niż to wynikałoby z tradycyjnego procesu ewolucji struktury produkcji w rozwijajacej się gospodarce. Zdecydowały o tym bogate złoża rudy żelaza na północy kraju, które zaczęto eksploatować jeszcze przed rewolucja przemysłową. Były one podstawą rozwoju hutnictwa szwedzkiego, które dzięki umiejętnościom hugenockich emigrantów z Francji rozwijało się już od końca XVII w. Gospodarka Szwecji w jej klasycznym, wolnorynkowym modelu w latach 1860-1910 rosła najszybciej na świecie.

Takie były, w ogromnym skrócie, materialne podstawy modelu szwedzkiego, który koncepcyjnie zarysowany został w latach 20 . XX w., a w życie zaczęto go wprowadzać w następnej dekadzie za rządów socjaldemokracji. Per Albin Hansson, premier Szwecji od 1932 r., tak formułował wcześniej zręby szwedzkiego modelu. Po pierwsze, podkreślał, że „kroczymy naprzód nie po to, by ustanowić dyktaturę klasy robotniczej, by zastąpić dawny ucisk nowym". Wyraźnie odcinał się w ten sposób od modelu komunistycznego. W konstruktywistycznej części swego wystąpienia stwierdzał, że „,idziemy naprzód po to, by - na mocnych podstawach demokracji - z poparciem większości, doprowadzić do równości pod względem statusu tych klas społecznych, które do tej pory napotykały bariery, by zlikwidować podziały klasowe. By w ten sposób uczynić Szwecję dobrym domem dla wszystkich Szwedów"7.

Sama koncepcja była, rzecz oczywista, godna pochwały. Problemy pojawiły się -jak zwykle - gdy przyszło formułować cele szczegółowe i stosować określone

${ }^{6}$ Za: M. Rojas, op. cit., s. 12.

7 Za: ibidem, s. 24. 
środki do ich realizacji. Koncepcja ta uzyskała w wystapieniach przyszłego wieloletniego premiera nazwę ,domu ludu” czy też „,domu ludowego” (folkhemmet). Taki dom ludowy miał być równie dobry dla wszystkich i wszystkim dawać sens przynależności do wspólnoty. Owo wspólnotowe podejście spotkało się $\mathrm{z}$ ogromnym poparciem społeczeństwa - w większości wiejskiego w swym pochodzeniu - które rewolucja przemysłowa i wzrost wydajności w rolnictwie przeniosły z wiejskich wspólnot do anonimowych miast.

Oferta nowej, organizowanej na różnych szczeblach wspólnoty była niesłychanie atrakcyjna dla nowych mieszkańców miast. Socjaldemokracja szwedzka, niezależnie od swoich egalitarystycznych i socjalnych zamierzeń, trafiła tutaj w dziesiątkę. Zresztą nie tylko ona. Gdy szuka się wyjaśnienia trwającego niegdyś przez pół wieku silnego poparcia dla Włoskiej Partii Komunistycznej, gdy w tym samym czasie poparcie dla komunistów na Zachodzie słabło z dekady na dekadę, to jest nim właśnie to, że znalazła ona podobną receptę na przyciąnnięcie do siebie tych, którzy $\mathrm{w}$ procesie industrializacji i poszukiwań poprawy bytu materialnego przenosili się ze wsi (i z Mezzogiorno) do miast, w których jednak czuli się samotni. Naukowy socjalizm i dyktatura proletariatu były może dla nich czymś niejasnym, ale organizowane nieustannie festyny, amatorskie zawody sportowe czy zgromadzenia partyjne łączone obowiązkowo z piknikiem dla rodzin członków partii pozwalały im odnaleźć się w nowym, anonimowym miejskim świecie.

Jak do tej pory, trudno dostrzec przyszłe problemy triumfującego przez kilka dziesięcioleci szwedzkiego modelu 1.0. Ci, którzy go wprowadzali, byli zreszta początkowo dość ostrożni w swoich przyrzeczeniach. Obok oczywistej równości wobec prawa (eliminacji przywilejów) i zapowiedzi rozszerzenia bezpłatnego państwowego szkolnictwa, takiej samej bezpłatnej opieki zdrowotnej oraz pomocy socjalnej potrzebującym, rządzący w latach 30. i 40. XX w. socjaldemokraci wierzyli w przestrzeganie starej socjalistycznej zasady: od każdego według jego możliwości, każdemu według jego pracy. Druga część tej zasady obowiązywała $\mathrm{z}$ oczywistych przyczyn w prywatnym szwedzkim przemyśle.

Jednakże oczekiwania tego rodzaju zachowań zderzać się zaczęły po II wojnie światowej $\mathrm{z}$ dwiema tendencjami o charakterze ideologicznym. Po pierwsze, z rosnącym - szczególnie silnie w latach 60 . XX w. - przekonaniem, że teraz oto nadszedł czas wprowadzenia w życie utopijnych egalitarystycznych rozwiązań w życiu gospodarczym i daleko idącej redystrybucji dochodu narodowego.

I po drugie, zderzało się $\mathrm{z}$ wiara utopijnych socjalistów - w rodzaju cytowanych Alvy i Gunnara Myrdalów - z potrzebą racjonalnego planowania gospodarczego i społecznego. Szwedzki model dobrego, domu ludowego implikował, że w tym domu są dobrzy rodzice, którzy wiedzą lepiej i przygotowywać będą swoje dzieci do dobrego życia, wskazując im drogę w tym właśnie kierunku (wybranym na podstawie wiedzy o gospodarce, społeczeństwie i polityce). Tak oceniał wewnętrzną dynamikę modelu szwedzkiego 1.0 cytowany już wcześniej Mauricio Rojas ${ }^{8}$, syn lewicowych emigrantów z Chile, którzy znaleźli azyl w Szwecji.

${ }^{8}$ M. Rojas, op. cit., s. 25. 
Obydwie te ideologiczne tendencje wspierało przekonanie socjaldemokratycznej elity o sile gospodarki szwedzkiej. Pamiętajmy, że gospodarka Szwecji rozwijała się najszybciej na świecie w okresie poprzedzającym rządy socjaldemokracji i utrzymała tę pierwszą lokatę (chociaż nie to samo tempo wzrostu PKB) także w okresie międzywojnia i II wojny światowej. Po tej ostatniej wojnie PKB per capita Szwecji był średnio dwa razy wyższy niż gdzie indziej w zrujnowanej przez wojnę Europie Zachodniej. Szwedzki eksport do odbudowującej się Europy stał się siłą napędową szwedzkiej gospodarki, która kontynuowała swą wysoką dynamikę wzrostu PKB także w latach 50. i 60 . XX w.

Reformatorom modelu szwedzkiego 1.0 wydawało się więc, że gospodarka jest $\mathrm{w}$ stanie znieść bez żadnych perturbacji i interwencje polityki przemysłowej, wraz z reformami rynku pracy, i planowaną ogromną ekspansję wydatków publicznych (głównie na cele rozbudowy państwa socjalnego). Tak to owi symboliczni dobrzy rodzice Mauricio Rojasa wytyczali w domu ludowym swoim dzieciom kierunki przemian ekonomicznych i społecznych. Polityka przemysłowa miała - w zamierzeniu twórców tych reform - połączyć realizację egalitarystycznych celów płacowych z przyspieszonymi zmianami strukturalnymi, unowocześniającymi szwedzką gospodarkę i mającymi uczynić ja jeszcze bardziej konkurencyjną w skali światowej.

Wprowadzenie scentralizowanych negocjacji płacowych stworzyło możliwości mikromajsterkowania $\mathrm{w}$ obszarze płac $\mathrm{w}$ przedsiębiorstwach. Wprowadzono zasady zbliżonego tempa wzrostu płac w poszczególnych branżach niezależnie od absolutnego poziomu i tempa wzrostu wydajności pracy. Utopijni reformatorzy uważali, że osiaggnie się $\mathrm{w}$ ten sposób dwa cele jednocześnie. Cel ideologiczny, czyli zmniejszenie różnic w poziomie płac, i cel ekonomiczny, czyli wyeliminowanie mniej wydajnych firm w poszczególnych branżach, które nie będą w stanie płacić coraz więcej swoim pracownikom. Ludzie ci, według koncepcji socjaldemokratycznych reformatorów, mieli przechodzić do bardziej wydajnych firm już istniejących i do nowych firm powstajacych w branżach nowoczesnych o wysokim poziomie wydajności pracy.

Z perspektywy historycznej można stwierdzić, że owi reformatorzy popełnili ten sam kardynalny błąd, jaki wprowadził do teorii ekonomii John Stuart Mill, który uważał, iż system tworzenia produktu i system jego podziału są od siebie całkowicie niezależne. Tymczasem między obu procesami - tworzenia i podziału - zachodzą silne związki. W gruncie rzeczy obecny kryzys Zachodu, dla którego kryzys strefy euro jest tylko epizodem, powstał właśnie z rozpowszechnionego przekonania o braku związków między tworzeniem a dzieleniem wytworzonego produktu9 ${ }^{9}$.

Ocenę wprowadzonych we wczesnych latach $60 . \mathrm{XX}$ w. rozwiązań zacznę od kwestii zmian $\mathrm{w}$ strukturze produkcji. Utopijni reformatorzy mieli rację, że przedsiębiorstwa o niższym poziomie i tempie wzrostu wydajności nie wytrzymaja konkurencji z bardziej wydajnymi krajowymi i zagranicznymi firmami i stosunkowo szybko upadna. Jednakże nie brali oni pod uwagę istnienia, znanych specjalistom, długotrwałych różnic w poziomie wydajności

${ }^{9}$ Zob. J. Winiecki, Kryzys strefy euro..., passim. 
pracy między branżami. Różnice te wynikały głównie $\mathrm{z}$ różnic $\mathrm{w}$ poziomie wyposażenia firm w kapitał (maszyny i urządzenia) oraz różnic szybkości zmian technicznych i organizacyjnych w branżach. Różnice w poziomie płac były $\mathrm{w}$ większej części naturalnym następstwem powyższych różnic. W efekcie, zwłaszcza $\mathrm{w}$ dominującym $\mathrm{w}$ ówczesnej gospodarce przemyśle przetwórczym (podstawie konkurencyjności gospodarki szwedzkiej), firmy w gałęziach przemysłu lekkiego, tradycyjnie charakteryzujących się znacznie niższą wydajnościa, wypadały z rynku bardzo szybko.

Jednocześnie reformatorzy przekonali się o błędności optymistycznego porzekadła: „,chcieć to móc”, a właściwie o utopijności wiary w planowanie gospodarcze. Nie wystarczy bowiem zaplanować, że pracownicy z likwidowanych firm przejda do pracy w firmach bardziej wydajnych czy w nowych gałęziach przemysłu przetwórczego.

\section{Tabela 1}

Udział przemysłu przetwórczego w wytworzonym PKB w Szwecji oraz wybranych krajach zachodnioeuropejskich w latach 1964-1980 (\%)

\begin{tabular}{|l|c|c|c|}
\hline \multicolumn{1}{|c|}{ Kraj } & $\mathbf{1 9 6 4}$ & $\mathbf{1 9 7 0}$ & $\mathbf{1 9 8 0}$ \\
\hline Szwecja & 27,7 & 25,0 & 21,7 \\
Austria & 33,2 & 33,7 & 28,3 \\
Belgia & 31,1 & 32,1 & 24,5 \\
Dania & $19,7 a$ & 18,5 & 16,4 \\
Finlandia & 21,8 & 24,3 & 25,6 \\
Holandia & $\ldots$ & 29,0 & 23,5 \\
Memorandum: & & & \\
Francja & 29,3 & 28,7 & 26,2 \\
Niemcy & 39,9 & 38,4 & 33,1 \\
Wielka Brytania & 30,0 & 28,1 & 22,1 \\
Włochy & 27,7 & 29,0 & 30,5 \\
\hline
\end{tabular}

Źródło: obliczono na podstawie OECD, National Accounts, t. 2: Detailed Tables 1964-81, Paris 1983.

Właściciele firm muszą mieć bodźce ekonomiczne, by zatrudniać pracowników z likwidowanych firm w mniej wydajnych branżach szwedzkiego przemysłu. Jeśli koszty owego zatrudnienia okażą się zbyt wysokie i/lub możliwości wzrostu popytu zbyt niskie, to do zatrudnienia zwalnianych czy nowo wchodzących na rynek pracy nie dojdzie. Podobnie, z punktu widzenia ekonomii, wyglądało planowane pojawienie się nowych firm w gałęziach o wysokim poziomie wydajności pracy lub pojawienie się całych nowych gałęzi. Przedsiębiorcy muszą mieć bodźce do podejmowania takich przedsięwzięć. I najwyraźniej ich nie mieli.

Tabela 1 pokazuje, że latach 1964-1980 udział przemysłu przetwórczego Szwecji w krajowym PKB zmniejszał się znacznie szybciej niż w innych, mniejszych i większych, rozwiniętych gospodarkach zachodnioeuropejskich. Już w 1970 r. udział szwedzkiego przemysłu przetwórczego w PKB był niższy 
niż we wszystkich rozwiniętych gospodarkach zachodnioeuropejskich, z wyjątkiem Danii. Dania bardzo wcześnie stała się zaawansowaną gospodarką opartą na usługach i konsekwentnie rejestrowała najniższe udziały przemysłu przetwórczego w PKB przez cały okres po II wojnie światowej.

W 1970 r. także Finlandia miała niższy udział przemysłu przetwórczego. Nie było to jednak - jak w przypadku Szwecji - rezultatem błędów w polityce ekonomicznej, lecz innego etapu rozwoju gospodarczego. Udział przemysłu przetwórczego w PKB ma - jak dowodzą tego liczne badania empiryczne charakter krzywoliniowy. Rośnie on do pewnego poziomu PKB per capita, aby następnie zacząć się zmniejszać ${ }^{10}$. Spośród rozwiniętych gospodarek zachodnioeuropejskich wymienionych w tabeli 1 Finlandia i Włochy były na nieco niższym poziomie rozwoju gospodarczego niż reszta uwzględnionych $\mathrm{w}$ niej krajów i udział przemysłu przetwórczego w PKB rósł w tych dwóch krajach przez cały okres 1964-1980.

Zamysł zmiany struktury przemysłu przetwórczego w kierunku przesunięcia zatrudnienia $\mathrm{z}$ gałęzi mniej wydajnych do bardziej wydajnych nie powiódł się. Rezultatem prowadzenia polityki zmniejszania różnic płacowych stało się po prostu szybsze kurczenie się udziału przemysłu przetwórczego $\mathrm{w}$ szwedzkim PKB i w zatrudnieniu, niż to miało miejsce $\mathrm{w}$ innych wysoko rozwiniętych gospodarkach. Natomiast zamysł zmniejszenia różnic płacowych powiódł się nadspodziewanie.

Zróżnicowanie płac między 1968 a 1984 r. zmniejszyło się o jedną trzecią we wszystkich przekrojach, a $\mathrm{w}$ odniesieniu do różnic $\mathrm{w}$ poziomie wykształcenia/kwalifikacji zmniejszyło się jeszcze bardziej. Pod względem tego ostatniego kryterium w 1991 r., na początku wielkiego kryzysu szwedzkiej gospodarki (a de facto modelu szwedzkiego 1.0), wynosiło mniej niż połowę tegoż zróżnicowania na początku wymienionego okresu.

Tabela 2 wskazuje wymownie, że trend ten utrzymał się - mimo wszystkich zmian w Szwecji - właściwie do dzisiejszego dnia. Szwecja ma spośród wybranych krajów zachodnioeuropejskich najmniejsze zróżnicowanie płac pod względem poziomu wykształcenia (czyli najniższe na świecie, gdyż poza Europa różnice te są z reguły znacznie większe). I to również nie mogło nie wpływać na strukturę bodźców: zarówno w kwestii stosunku do wysiłku, jakiego wymaga podnoszenie kwalifikacji, jak i innych kwestii, na przykład opłacalności większego wysiłku w ogóle.

Powyższa egalitaryzacja następowała w warunkach bardzo szybkiej od lat 60. XX w. ekspansji państwa opiekuńczego. W okresie trzydziestu lat, od $1964 \mathrm{r}$. do szczytu kryzysu w 1993 r., udział wydatków publicznych w szwedzkim PKB wzrósł z 31,4\% do niebotycznego poziomu $71,7 \%$. Był to jedyny przypadek takiego wzrostu odnotowany w historii gospodarczej.

Nie mogło to nie mieć konsekwencji także w obszarze płac i w ogóle dochodów jednostek. Nie wystarczyły zyski przedsiębiorców i podatki, zwłaszcza PIT, zaczęły rosnąć równie szybko. Skłonności egalitarne, których Szwedzi nie

${ }^{10}$ Zob. J. Winiecki, The Distorted World of Soviet-Type Economies, Routledge, London and Pittsburgh University Press, 1988, rozdz. III i cytowana tam literatura nt. zmian strukturalnych w rozwoju gospodarczym. 
Tabela 2

Różnice poziomu płac w zależności od poziomu wykształcenia w wybranych krajach zachodnioeuropejskich

(średnia z lat 1991-2005 w \%)

\begin{tabular}{|c|c|c|c|c|}
\hline \multirow[t]{2}{*}{ Kraj } & \multicolumn{2}{|c|}{$\begin{array}{c}\text { Płace osób } \\
\text { z wyższym wykszt./ } \\
\text { płace osób } \\
\text { ze średnim wykszt. }\end{array}$} & \multicolumn{2}{|c|}{$\begin{array}{c}\text { Płace osób } \\
\text { ze średnim wykszt./ } \\
\text { płace osób } \\
\text { z wykszt. niżej średniego }\end{array}$} \\
\hline & Mężczyźni & Kobiety & Mężczyźni & Cobiety \\
\hline Szwecja & 30,8 & 22,9 & 17,9 & 11,4 \\
\hline Austria & 58,0 & 53,7 & 37,5 & 39,0 \\
\hline Belgia & 37,5 & 31,9 & 17,4 & 24,5 \\
\hline Dania & 35,4 & 33,1 & 30,3 & 32,3 \\
\hline Finlandia & 53,0 & 39,5 & 23,0 & 22,3 \\
\hline Holandia & 43,0 & 36,1 & 30,1 & 26,7 \\
\hline Szwajcaria & 48,4 & 40,2 & 96,0 & 58,9 \\
\hline Memorandum: & & & & \\
\hline Francja & 67,2 & 58,6 & 21,1 & 27,8 \\
\hline Niemcy & 45,2 & 42,0 & 19,5 & 24,7 \\
\hline Wielka Brytania & 65,3 & 71,4 & $\ldots$ & ... \\
\hline
\end{tabular}

Źródło: H. Strauss, Ch. De la Maisonneuve, The Wage Premium on Tertiary Education. New Estimates for 21 OECD Countries, OECD Economics Department, Working Papers, nr 589, Paris 2007.

pozbyli się zresztą do dziś dnia, kazały socjaldemokratycznym politykom wprowadzić ostre zróżnicowanie stawek podatku PIT. W konsekwencji spłaszczenie dochodów było w praktyce jeszcze większe, niż wynikałoby to z przytaczanych powyżej różnic.

Wreszcie, istniejące jeszcze niewielkie różnice niwelowało skutecznie szwedzkie państwo socjalne, w którym coraz szersza gama świadczeń do początków lat 90. ubiegłego wieku była praktycznie darmowa. Ale temu chłopskiemu z pochodzenia społeczeństwu takie rozwiązania bardzo się podobały. Jak to kiedyś celnie sformułowała moja angielska znajoma, córka konserwatywnego posła partii konserwatywnej o thatcherowskiej orientacji, Szwedzi nie dostają płac za pracę, tylko kieszonkowe, a całą resztę od zasiłku po urodzeniu dziecka do zasiłku pogrzebowego daje im państwo.

Tyle że ,,idee mają swoje konsekwencje”, jak to sformułował wspomniany przeze mnie w innym kontekście John Stuart Mill. Ponieważ wbrew jego poglądom istnieją silne związki między sferą wytwórczości a sferą podziału, więc konsekwencje te były poważne i niekorzystne dla ekonomicznych fundamentów socjaldemokratycznego państwa socjalnego. Państwo niańka, czy też raczej - oschła i bezosobowa ochmistrzyni, regulujące życie każdego Szweda nie tylko w obszarze płac i dochodów oraz świadczeń socjalnych, funkcjonowało nadal. Ale to ono właśnie zostało poświęcone na ołtarzu kryzysu modelu szwedzkiego 1.0. Do tego wrócę w następnej części artykułu. Na razie jednak muszę jeszcze powrócić do ekonomicznych skutków egalitarystycznych tendencji i rosnącego socjalu. 
Szwecja jest w skali świata niewielką gospodarką, bardzo zależną od gospodarki światowej. Jej eksport zawsze stanowił znaczna część PKB. Oznaczało to zależność od otwartego, liberalnego systemu handlu międzynarodowego, do którego świat zachodni powrócił po II wojnie światowej - z wielką korzyścią także dla Szwecji. Ale ciagnnięcie korzyści z międzynarodowego podziału pracy zależy nie tylko od ram zewnętrznych, lecz przede wszystkim od wydajności pracy, produktywności kapitału i innowacyjności firm uczestniczących w handlu międzynarodowym. Tymczasem Szwecja stała się gospodarką, w której bodźce do tego, by pracować raczej, niż udać się na dłuższe wakacje, by zarabiać i oszczędzać raczej, niż się zadłużać, by wprowadzać coraz to nowe rozwiązania raczej, niż solidnie robić to, co do tej pory (to Szwedzi potrafia nadal!), stawały się z upływem lat coraz słabsze. Kolektywistyczne rozwiązania demoralizowały nie tylko homo sovieticus, lecz także i homo Svedensis (choć z pewnością nie do tego samego stopnia!).

Stąd konkurencyjność szwedzkich firm z upływem lat słabła. Szwedzkie wielkie firmy międzynarodowe broniły się przed tym, wyprowadzając część produkcji do zagranicznych filii i oddziałów; mniejsze firmy krajowe nie miały takich możliwości. Ale i w przypadku tych pierwszych, i tych drugich miało to wpływ na wzrost deficytu w bilansie handlowym Szwecji z zagranica, który powiększał się co kilka lat poza bezpieczne granice. Jedynym instrumentem korygującym w dyspozycji władz była dewaluacja korony szwedzkiej; z instrumentu tego korzystano wielokrotnie.

Ale stosowanie tego instrumentu, chociaż przejściowo poprawiało konkurencyjność szwedzkiego eksportu, miało też swoje konsekwencje dla poziomu płac i szerzej: poziomu konsumpcji w Szwecji. Każda dewaluacja czyniła towary importowane droższymi. W niewielkim kraju znaczna część dóbr konsumpcyjnych pochodzi z importu; wzrost cen importu czyni te dobra relatywnie mniej dostępnymi dla jego mieszkańców. Jeśli teraz powyższe efekty kolejnych dewaluacji połączy się z wysokim opodatkowaniem, to trudno się dziwić, że płace realne netto po opodatkowaniu przestały w Szwecji rosnąc około $1975 \mathrm{r}$. i pozostawały na tym samym poziomie przez następnych lat trzydzieści (do 2005 r.). Ten brak wzrostu płac realnych netto stał się kolejnym - choć wtórnym - czynnikiem osłabiającym strukturę bodźców w szwedzkiej gospodarce.

Warto przez chwilę spojrzeć na problemy Szwedów z bodźcami ekonomicznymi z perspektywy historycznej i porównawczej. W ciagle postępującym kryzysie strefy euro podkreśla się negatywne konsekwencje dla konkurencyjności i poziomu życia braku krajowej polityki kursowej i w efekcie niemożliwości przeprowadzenia dewaluacji przez kraje zadłużone. Pozostaje jedynie bolesna operacja redukcji płac realnych i innych dochodów w gospodarce - twierdza krytycy. Zgoda. Tyle że posiadanie własnej waluty i jej dewaluacja pomaga wprawdzie (przejściowo) w poprawie konkurencyjności, natomiast nie zmienia efektów płacowych (czy szerzej: dochodowych). Po dewaluacji greckiej, portugalskiej czy hiszpańskiej waluty spadek poziomu płac realnych i tak byłby nieuchronny. Jedyna różnica jest nie tyle ekonomiczna, ile polityczna. Politycznie łatwiej jest bowiem zdewaluować krajową walutę, niż dokonać cięć $\mathrm{w}$ płacach nominalnych. W końcu trudniej jest demonstrować przeciwko 
kursowi walutowemu niż przeciwko rządowi obcinającemu pobory urzędnikom lub obcinającemu dotacje na przykład dla nierentownych kopalni (przypadek nie tylko Polski, lecz także m.in. Hiszpanii)...

\section{MODEL SZWEDZKI 2.0: OKROJONE PAŃSTWO SOCJALNE I POWRÓT OBYWATELSKICH WOLNOŚCI WYBORU}

Ostry kryzys pierwszej połowy lat 90 . ubiegłego wieku, który położył kres przedstawianemu w części III modelowi 1.0, zdeterminowały zarówno negatywne konsekwencje modelu szwedzkiego dla dynamiki gospodarczej, jak i globalne zmiany tendencji ekonomicznych i techniczno-organizacyjnych, które dotknęły Szwecję silniej niż wiele innych zachodnich gospodarek. Zaczać jednak należy od przyczyn wewnętrznych.

Pisałem wyżej o szybko kurczącym się szwedzkim przemyśle przetwórczym (zob. też tabela 1). Jedynym miejscem, gdzie istniały możliwości trwałego wzrostu zatrudnienia, był więc sektor usług. I rzeczywiście zatrudnienie w sektorze usług rosło bardzo szybko. Problemem był jednak fakt, że w egalitarystycznej koncepcji folkhemmet i w ogóle socjalistycznej mentalności dominowało podejście uniformizujące rozmaite usługi, niezależnie od potrzeb i preferencji jednostek korzystających $\mathrm{z}$ tych świadczeń. Normalnie usługi odpowiadaja na zróżnicowany popyt zgłaszany przez tych, którzy gotowi sa za tę indywidualizację usług zapłacić. Ale tam, gdzie państwo jest monopolista w świadczeniu usług, brak bodźców do dywersyfikacji podaży. Państwo niańka (czy raczej oschła, obojętna na indywidualne potrzeby ochmistrzyni) wyraźnie preferuje usługi jednorodne, świadczone według zasady: take it, or leave it. Żadnej wolności wyboru!

Jeśli połączyć uniformizm świadczeń z usytuowaniem szwedzkiego państwa socjalnego $\mathrm{w}$ sektorze publicznym, to nieuchronnym efektem tego mariażu musiała być biurokratyzacja systemu oświaty, ochrony zdrowia i świadczeń społecznych, a także miękkie ograniczenie budżetowe sektora publicznego. Wiadomo, że władze, resortowe czy terenowe, patrzą życzliwiej na potrzeby podległego im personelu niż prywatny pracodawca, który musi się liczyć z kosztami.

Dodać do tej mieszanki należy wynikająca z biurokratyzacji i uniformizmu niechęć do eksperymentowania i innowacji. Konsekwencją interakcji powyższych tendencji stała się spadająca wydajność pracy sektora publicznego. Dobrą ilustrację stanowi artykuł Fredricka Segerfeldta, który wskazywał między innymi na niekorzystne zmiany $w$ szwedzkiej ochronie zdrowia. Jeszcze w 1975 r. lekarz przyjmował w Szwecji podczas dyżuru średnio dziewięciu pacjentów, gdy od wielu lat liczba ta nie przekracza czterech! Lekarze zwracali uwagę, że 50-80\% czasu muszą poświęcać biurokratycznym zajęciom (troska o zgodne z przepisami wydatkowanie publicznych pieniędzy kosztuje!) ${ }^{11}$.

${ }^{11}$ F. Segerfeldt, The Not-So-Super Model, ,Wall Street Journal” z 24 stycznia 2006 r. 
Póki było to możliwe, spadek wydajności kompensowano wzrostem zatrudnienia w publicznej służbie zdrowia: do lat 90. XX w. liczba lekarzy i pielęgniarek podwoiła się. W którymś momencie możliwości dalszej ekspansji sektora publicznego musiały napotkać barierę finansowania. U progu lat 90 . udział wydatków publicznych w PKB, od dziesięcioleci najwyższy na świecie, zbliżył się do granicy 70\%. Rosnący poziom opodatkowania rzeczywiście odzwierciedlać zaczynał cytowany wcześniej żart, że pracujący Szwedzi dostaja nie płace, tylko kieszonkowe.

Zderzenie się z bariera finansowania sektora publicznego przyspieszyła egalitarystyczna polityka płac prowadzona w Szwecji od późnych lat 60. XX w. W teorii ekonomii istnieje pojęcie ,choroby Baumola”. William J. Baumol stwierdził, że presja polityczna i związkowa na wzrost płac w sektorze usług, gdzie tempo wzrostu wydajności pracy jest niższe niż w sektorze przemysłu, szybko podnosi koszty tych usług, zwłaszcza publicznych. W negocjacjach płacowych bowiem obie strony: pracobiorcy i pracodawcy, znajduja się po tej samej stronie barykady, czerpiąc swoje dochody z podatków ${ }^{12}$. W rezultacie koszty szybko rosną w obliczu wolno rosnącej (lub spadającej, jak w cytowanym przypadku ochrony zdrowia) wydajności. Władze publiczne mają wówczas tylko dwie możliwości: albo podwyższać coraz bardziej stopę opodatkowania, albo redukować poziom oferowanych świadczeń. Taką barierę napotkały władze szwedzkie właśnie w pierwszej połowie lat 90 .

Siła oddziaływania bariery finansowej byłaby może mniejsza, czyli model szwedzki 1.0 przetrwałby jeszcze kilka czy może nieco więcej lat, gdyby nie wzmiankowane zmiany $\mathrm{w}$ gospodarce światowej i problemy szwedzkiego przemysłu w dostosowaniu się do zmienionych reguł konkurencji. Otóż przełom lat 60. i 70. XX w. był czasem przemian w strukturze gospodarek krajów uprzemysłowionych. Co najmniej od lat 20. ubiegłego wieku rolę dźwigni rozwoju gospodarczego pełniły branże charakteryzujące się ekonomią skali. Czołowe branże przemysłu szwedzkiego miały takie właśnie cechy i na tej fali szwedzkie firmy zajmowały wysoce konkurencyjne pozycje $\mathrm{w}$ produkcji i wymianie międzynarodowej.

Dodajmy też, że triumfalny pochód nie tylko modelu szwedzkiego 1.0, lecz także generalnie idei kolektywistycznych $\mathrm{w}$ świecie wspierany był silnie przez takie tendencje. Pisałem o tym już w latach 80., że korzyści ekonomii skali wytworzyły fałszywe wrażenie o źródłach bogactwa narodów. W warunkach gdy każde podwojenie skali produkcji przynosiło wzrost wydajności rzędu 20-30\%, bogactwo wydawało się zjawiskiem pojawiającym się jak Deus ex machina. I im większa machina (czytaj: firma), tym więcej bogactwa ${ }^{13}$.

Wielu ekonomistów, a już na pewno polityków, uznawało zjawisko dominacji przemysłów opartych na rosnącej skali produkcji za cechę niezmienna w rozwoju produkcji i w podziale wytworzonego bogactwa. Stąd też brała się

\footnotetext{
${ }^{12}$ W. J. Baumol, Macroeconomics of Unbalanced Growth: The Anatomy of Urban Crises, „American Economic Review" 57, 1967, nr 3, s. 415-426.

13 J. Winiecki, Economic Prospects - East and West, Centre for Research into Communist Economies, London 1987, s. 69-70.
} 
między innymi popularność prognozowania. Także w Szwecji tendencja prognozowania wzrostu produkcji, dochodów, podatków i wydatków publicznych (zwłaszcza państwa socjalnego) na dziesiątki lat do przodu była zjawiskiem powszechnym.

Trendy $\mathrm{w}$ gospodarce światowej pchnęły jednak tę gospodarkę $\mathrm{w}$ innym kierunku. Z upływem lat 70. XX w. coraz silniejsza pozycję motoru wzrostu gospodarczego zajmować zaczęły branże przemysłu (i nie tylko przemysłu!), w których o konkurencyjnym sukcesie decydowały przedsiębiorczość, innowacyjność i dostosowywanie produkcji do zindywidualizowanych wymagań grup i pojedynczych klientów (kastomizacja - customization). Elektronika przemysłowa i elektronika konsumencka, optoelektronika, produkcja komputerów osobistych, produkcja narzędzi dla potrzeb nauki i prac technicznych, chemia małotonażowa, produkcja farmaceutyków i wiele innych odgrywać zaczęły rolę dominująca. Zmiany były nieraz zaskakujące. Przemysł samochodów osobowych pod wpływem innowacji i kastomizacji potrafił przekształcić się z branży opartej na wielkości skali produkcji w branżę innowacyjną i dopasowująca swoją ofertę produkcyjną nawet do życzeń pojedynczych klientów.

Dominująca rola przedsiębiorczości, innowacyjności i kastomizacji miała daleko idące konsekwencje szczególnie w dwóch obszarach. Po pierwsze, odwróciła ona trend rosnącej średniej wielkości przedsiębiorstwa, mierzonej wielkością produkcji i zatrudnienia. Dzięki nowoczesnym technologiom, umożliwiającym inną organizację pracy, mniejsze firmy okazały się zdolne do konkurowania $\mathrm{z}$ tradycyjnymi gigantami $\mathrm{w}$ swoich branżach, a ich większa innowacyjność wzmacniała jeszcze tę przewagę. Małe i średnie przedsiębiorstwa (MSP) zaczęły zapewniać też coraz większą część zatrudnienia i w mniejszym nieco stopniu także produkcji w rozwiniętych gospodarkach Zachodu. Drugim obszarem wielkich zmian w tych gospodarkach okazała się dominująca rola tychże przedsiębiorczych, innowacyjnych i zdolnych do kastomizacji małych i średnich firm w sektorze usług o wysokiej intensywności kapitału ludzkiego - szybko zwiększających swój udział w PKB i zatrudnieniu.

Zmiany powyższe wpłynęły niekorzystnie zarówno na szwedzki przemysł przetwórczy - podstawę konkurencyjnej potęgi Szwecji - jak i na skolektywizowany sektor usług w obszarze edukacji, ochrony zdrowia i ubezpieczeń społecznych. Zacznę od przemysłu przetwórczego. Szwedzkie wielkie firmy w gruncie rzeczy utrzymywały swoją pozycję lub ją wzmacniały w tych samych gałęziach wytwórczości nierzadko od końca XIX w. Stabilność firm miała pozytywne następstwa $\mathrm{w}$ warunkach liniowego niemal wzrostu produkcji od lat 50. do wczesnych lat 70 . XX w. Współpraca menedżmentu i związków zawodowych stanowiła $\mathrm{w}$ tych warunkach nawet element wzmacniajacy niekiedy sprawność produkcyjna tych firm.

Jednakże zmiana tendencji strukturalnych, o których była mowa powyżej, stała się elementem destabilizującym relacje wewnętrzne. Stosunkowo łatwo było utrzymać dobre relacje wewnątrz firmy, gdy dzielono owoce wzrostu; znacznie gorzej kolektywistyczne rozwiązania sprawdzały się w warunkach innowacji i wynikających stąd zmian organizacyjno-technologicznych. A jeszcze gorzej, gdy popyt na szwedzkie wyroby zaczął spadać i dokonywać trzeba było cięć $\mathrm{w}$ zatrudnieniu. 
W drugiej połowie lat 80. i w latach 90. duże firmy świata zachodniego dostrzegły swoje słabości i rozpoczęły procesy reorganizacyjne. Przyjęły one nazwę spłaszczania struktur zarządzania (downsizing). Wielu kierowników i specjalistów średniego szczebla było zwalnianych, likwidowano (wyprowadzono poza firmę via outsourcing) produkcję części i materiałów, które nie miały kluczowego znaczenia dla tworzenia wartości dodanej. Zaczęto tworzyć wewnątrzfirmowe centra innowacyjności (tzw. intrapreneurship). Proces odchudzania firmy i jej proinnowacyjnego podejścia było względnie łatwo przeprowadzić w kulturze anglosaskiej. Okazywało się to jednakże bariera często trudną do przezwyciężenia w szwedzkiej kulturze kolektywistycznego folkhemmet.

Problemy $\mathrm{z}$ adaptacją dostrzegali $\mathrm{w}$ latach kryzysu także i szwedzcy ekonomiści. Na przykład Klas Eklund zwracał uwagę na szczególnie negatywne konsekwencje egalitaryzacji płac w gospodarce, w której indywidualizm przedsiębiorcy, innowatora czy nawet inicjatywa poszczególnych pracowników przedsiębiorstwa staje się ważnym źródłem przewagi ${ }^{14}$. Najmniejsze różnice w świecie zachodnim w poziomie płac (zob. m.in. tabela 2) nie sprzyjały nagradzaniu podejmowanych inicjatyw.

O ile we wcześniejszej fazie kurczenie się szwedzkiego przemysłu przetwórczego w relacji do PKB dotykało głównie firm i ich pracowników w niskowydajnych branżach przemysłu, o tyle opisane wyżej przemiany powodowały osłabienie konkurencyjności wielu spośród tych najlepszych, czołówki szwedzkich firm. Odbijało się to na bilansie handlowym i płatniczym Szwecji, powodując częstsze korekty dewaluacyjne szwedzkiej korony. A w konsekwencji, pamiętajmy, także wzrost cen importowanych dóbr konsumpcyjnych. Jakikolwiek wzrost wydajności pracy konsumowany był albo przez rosnące opodatkowanie na potrzeby wzrostu udziału sektora publicznego w PKB, albo przez dewaluacje korony. Na wzrost płac realnych netto po opodatkowaniu brakowało zasobów już od połowy lat 70.; natomiast koszty pracy wzrosły o ponad $50 \%$.

Wreszcie, któryś kolejny kryzys bilansu płatniczego w warunkach recesji w gospodarce europejskiej, a więc u głównych odbiorców szwedzkiego eksportu, uruchomił lawinę kryzysu. Zaczęły się schody, wedle określenia słynnego polskiego kawalerzysty. Pełne zatrudnienie (tzn. bezrobocie rzędu 2-3\%), zostało zastapione rosnacym bezrobociem. W latach kryzysu (1990-1994) zniknęło pół miliona miejsc pracy, ponad $12 \%$ całości siły roboczej.

Warto przy okazji zauważyć, że problemy przemysłu szwedzkiego sa - co do ich rodzaju - dość podobne do problemów rozwojowych i problemów konkurencyjności gospodarek komunistycznych. Dla nich też przesunięcie się centrum dynamiki rozwojowej do branż o dominującej roli przedsiębiorczości, innowacyjności i kastomizacji, a więc stanowiących przeciwieństwo cech gospodarki centralnie planowanej i administrowanej, pchnęło je w kierunku powolnego (a później przyspieszonego) upadku ${ }^{15}$. Oczywiście w wypadku Szwecji skala

${ }^{14}$ K. Eklund, Sveriges tillvaxtproblem, w: Marknad och politik, Dialogos, Lund 1994, cyt za: M. Rojas, op. cit., s. 47.

15 J. Winiecki, The Distorted World..., rozdz. 3. 
tego pogorszenia dynamiki i spadku konkurencyjności w handlu zagranicznym zaczynała się od nieporównanie wyższego poziomu i była też wyraźnie mniejsza. Niemniej przyczyny tego spadku były dość podobne: nadmiar uniformizacji, planowania i niedomiar bodźców do zmian adaptacyjnych i innowacji.

Po raz pierwszy w Szwecji triumfującego folkhemmet (modelu 1.0) cięcia dotknęły rosnący bez umiarkowania sektor publiczny. Przez trzydzieści lat sektor prywatny nie generował netto nowych miejsc pracy, a równolegle udział zatrudnienia w sektorze publicznym rósł niepowstrzymanie. W 1993 r. sektor publiczny zatrudniał $42 \%$ wszystkich pracujących (najwyższy wskaźnik wśród krajów OECD)! Tym razem nie znalazły się żadne nowe zasoby, które mogłyby zostać jeszcze wyżej opodatkowane. Trzeba było ciąć także zatrudnienie w sektorze publicznym i same świadczenia.

Jak to podkreślałem wcześniej, oryginalny model szwedzki był modelem opartym na dwóch filarach: państwa socjalnego oraz, jak to się często w literaturze zachodniej określa, państwa niańki. Był to też projekt ideologiczny. Zachowanie kapitalistycznego modelu produkcji i socjalizacja efektów dochodowych tegoż modelu produkcyjnego tworzyć miało materialne podstawy coraz wyższego poziomu redystrybucji $\mathrm{w}$ ramach państwa socjalnego. Jednocześnie kolektywiści - w tym i szwedzcy - zawsze odczuwaja potrzebę ideologicznej edukacji (czy czasem wręcz indoktrynacji) społeczeństwa, które powinno być przekonane o wyższości realizowanego modelu. Stąd uniformizacja sfery edukacji: od przedszkolnej do studiów wyższych oraz utrzymanie całości tej edukacji w rękach władz publicznych.

W modelu szwedzkim 1.0, jak w modelu sowieckim, nie do pomyślenia były prywatne przedszkola czy szkoły, gdzie młodzieży mogłaby być wpajana inna filozofia społeczna niż obowiązująca w Szwecji. Tutaj: idea dobrego, kolektywistycznego domu ludowego. Państwo niańka, opiekując się obywatelami od przedszkola, dbać miało także o to, by młodzi ludzie wyrastali w przekonaniu, że żyja w najlepszym ze światów. Oczywiście w przypadku Szwedów ten model ideologiczny znalazł nieporównanie większe wsparcie ludności niż w przypadku któregokolwiek z niegdysiejszych krajów komunistycznych.

Po pierwsze, część redystrybucyjna programu wspierana była przez gospodarkę, która przez bardzo długi okres rosła najszybciej na świecie i na starcie modelu folkhemmet, a także jeszcze długo potem, była jedną $\mathrm{z}$ kilku najzamożniejszych i najbardziej konkurencyjnych gospodarek świata. Innymi słowy, przez dłuższy czas ciaggle było co dzielić.

Po drugie, w chłopskim z pochodzenia społeczeństwie koncepcja urawniłowki (eliminacji różnic w poziomie płac, uniformizacji świadczeń państwa socjalnego itd.), znajdowała entuzjastyczne wręcz poparcie większości. Jednocześnie z racji wysokiego poziomu zamożności (PKB per capita) znacznie wolniej pojawiały się empiryczne dowody negatywnych konsekwencji takich koncepcji gospodarczych i społecznych. Sprawnie funkcjonująca administracja również pomagała łagodzić stan rzeczywisty, to znaczy coraz wolniej tworzonego bogactwa.

Na fali kryzysu lat 1990-1994, dramatycznego wzrostu jawnego bezrobocia (bezrobocie ukryte w postaci rozmaitego rodzaju szkoleń istniało od dawna), pierwszych bolesnych cięć i zatrudnienia, i samych świadczeń dla beneficjentów 
państwa socjalnego musiało dojść do pewnych przewartościowań w partii socjaldemokratycznej i w jej intelektualnym zapleczu. Efekty instytucjonalne i ekonomiczne tych przewartościowań możemy prześledzić, przyglądając się Szwecji w latach 90. XX w. i w pierwszym dziesięcioleciu obecnego stulecia.

Dla opozycji, która doszła do władzy na fali kryzysu (po raz drugi dopiero od 1928 r.!), było dość oczywiste, że i w gospodarce, i w życiu społecznym recepta powinno być więcej wolności. I w tym kierunku poszły też liczne rozstrzygnięcia podejmowane przez te rządy na początku lat 90. Z drugiej strony, elity polityczne i intelektualne szwedzkiej socjaldemokracji, ściśle splecione ze sobą, stanęły przed prawdziwym dylematem, czasem nie do końca uświadamianym. Prawdziwym problemem dla nich było znalezienie odpowiedzi na dramatyczne pytanie: co ratować? W płaszczyźnie ekonomicznej szło o uratowanie jak najwięcej z państwa socjalnego, a w płaszczyźnie politycznej - kolektywistycznej, bazującej na zaufaniu społecznym ideologii i w konsekwencji dotychczasowej roli państwa niańki.

W jakimś stopniu samo życie, czyli kierunek ewolucji strukturalnej w gospodarce światowej, zadecydowało o wyborach socjaldemokratów po ich ponownym dojściu do władzy w połowie lat 90. Ewolucja gospodarki w kierunku wzrostu znaczenia przedsiębiorczości, innowacyjności i kastomizacji wskazywała jednoznacznie na wzrost wolności ekonomicznej jako ni e z będny warunek sukcesu przemian w tym kierunku. Większy zakres i skala swobód w działalności gospodarczej jednak nie wystarczały. Jednostki wykazujące się inicjatywą (przedsiębiorczością itd.) potrzebują swobody wyboru nie tylko w kwestii, co, gdzie i jak produkować, lecz także w obszarze ich indywidualnych i obywatelskich wyborów.

Dlatego socjaldemokraci postanowili (zapewne z ciężkim sercem) poświęcić państwo niańkę na ołtarzu ożywienia i poprawy konkurencyjności gospodarki, co zwiększyć miało szanse przetrwania państwa socjalnego w możliwie mało ograniczonym stanie. I tak się też stało. Socjaldemokraci za dwóch kolejnych rządów premiera Gorana Perssona poszli podobną drogą. Też obniżali absurdalnie wysokie podatki i jednocześnie ograniczali wydatki publiczne. Wystarczy spojrzeć na tabelę 3, aby dostrzec zarówno ciagłość kierunku zmian w udziale wydatków publicznych w PKB, jak i zmian w poziomie wolności ekonomicznej.

Najwyższy udział sektora publicznego w PKB w początkach lat 90. sięgnął $72,8 \%$. Rządzący wówczas konserwatyści i liberałowie zredukowali wydatki (i podatki) tak, że gdy odchodzili, wskaźnik ten wynosił około 65\%. Ciągle był to wskaźnik szokująco wysoki, ale trzeba pamiętać, że cztery lata rządów konserwatywno-liberalnych w warunkach najostrzejszego kryzysu od lat 30. XX w. zdjęły tego ciężaru 6-7 punktów procentowych PKB. Ciężaru, ponieważ trzeba pamiętać, że wskaźnik WP/PKB ma jeszcze jedną interpretację. Mianowicie definiuje on $\mathrm{z}$ grubsza, jakie bodźce pracujący w danej gospodarce narodowej mają do tego, by pracować, zarabiać, oszczędzać i inwestować. Pokazuje bowiem, ile zabiera się pracującym z tego, co wytworzyli.

$\mathrm{Z}$ tej perspektywy można powiedzieć, że rządzący po nich przez 8 lat socjaldemokraci kontynuowali politykę dostosowań państwa socjalnego do możliwości tworzenia bogactwa przez szwedzką gospodarkę. Do połowy 
Tabela 3

Zmiany w Szwecji relacji wydatków publicznych do PKB (WP/PKB) oraz wskaźnika wolności ekonomicznej (WWE)

tworzonego przez Heritage Foundation i „Wall Street Journal” w latach 1995-2011

\begin{tabular}{|l|c|c|c|}
\hline \multicolumn{2}{|c|}{ WP/PKB } & \multicolumn{2}{c|}{$\begin{array}{c}\text { WWE mierzony w punktach } \\
\text { w skali 0-100 (maksimum }=100)\end{array}$} \\
\hline 1995 & 64,9 & 1995 & 61,4 \\
1998 & 58,8 & 1998 & 64,0 \\
2001 & 54,5 & 2001 & 66,6 \\
2004 & 54,2 & 2004 & 70,1 \\
2007 & 51,0 & 2007 & 69,3 \\
2009 & 55,2 & 2009 & 70,5 \\
2011 & 51,9 & 2011 & 71,9 \\
\hline
\end{tabular}

Źródło: „,OECD Economic Outlook” 2011, nr 1, odnośnie do relacji WP/PKB oraz 2011 - Index of Economic Freedom, The Heritage Foundation i Dow Jones Company, Washington, D.C., 2011.

uprzedniej dekady zdjęli oni następne 10 punktów procentowych z udziału wydatków publicznych w PKB. Nie da się ukryć, że musiało to się odbić na ilości i jakości usług szwedzkiego państwa socjalnego. Ostatni okres to okres kolejnych rządów konserwatywno-liberalnych, które przetrwały początek i kontynuację globalnego kryzysu finansowego i ich rządy zostały na tyle dobrze ocenione przez wyborców, że w głębi obecnego kryzysu wygrali kolejne wybory i po raz pierwszy od I wojny światowej rządzą obecnie drugi raz z rzędu.

Ale wracajmy do efektów zmian budżetowych i regulacyjnych w latach 90 . XX w. i pierwszej dekadzie obecnego wieku. Pamiętajmy, że kolejne rządy postawiły na deregulację oraz niższe (choć ciagle bardzo wysokie) podatki. Zmieniło to pozycję Szwecji w rankingach wolności ekonomicznej. Od lat 70. ubiegłego wieku, gdy takie rankingi zaczęły wchodzić w modę, Szwecja wraz z innymi krajami skandynawskimi zresztą znajdowała się daleko: w czwartej-piątej dziesiątce ocenianych krajów.

Szwecja głównie pod wpływem kryzysu wczesnych lat 90., a inne kraje skandynawskie głównie pod wpływem racjonalnej oceny trendów gospodarczych zdecydowały o konieczności zwiększenia wolności ekonomicznej. Ich pozycja ( $\mathrm{z}$ wyjątkiem bogatej w paliwa kopalne Norwegii) zaczęła rosnąć we wzmiankowanych rankingach. W odniesieniu do rankingu Heritage Foundation i dziennika „Wall Street Journal” postęp w skali i zakresie wolności gospodarczej od 1995 do 2011 r. widać w tabeli 3. Natomiast jeśli idzie o miejsca w światowym rankingu, to w pierwszym rankingu dla lat 1993-1995 Szwecja zajmowała miejsce na początku czwartej dziesiątki, w 2001 r. miejsce 29-31, a w 2011 r. już miejsce 22 .

Wolność ekonomiczna, chociaż ma cenny walor filozoficzny, jak każdy wymiar wolności, jest jednak także i środkiem do celu, którym jest poprawa efektywności gospodarki, a w efekcie także przyspieszenie wzrostu gospodarczego i zatrudnienia. Spróbujmy więc ocenić efekty większej wolności gospodarczej. Zacznę od przemysłu przetwórczego, podstawy konkurencyjności Szwecji w handlu międzynarodowym. 
W punkcie III zwróciłem uwagę na fakt, że wprowadzona w latach 60 . ubiegłego wieku polityka zmniejszania różnic w poziomie płac niezależnie od poziomu wydajności pracy uczyniła niekonkurencyjną sporą część pracochłonnych gałęzi szwedzkiego przemysłu lekkiego. W rezultacie udział przemysłu przetwórczego $\mathrm{w}$ tworzeniu PKB zmniejszył się bardzo znacznie w latach 1964-1980 (tabela 1). Od tego czasu udział ten był najniższy spośród krajów OECD, z wyjątkiem Danii (wysoko rozwiniętej gospodarki opartej na usługach).

Efekty wzrostu wolności gospodarczej po kryzysie wczesnych lat 90 . pokazuja relatywne zmiany na lepsze. Korzystne zmiany były dwojakie. O ile w dnie kryzysu udział przemysłu w PKB wynosił $16 \%$, o tyle w 2000 r. udział ten zwiększył się do 19,3\%; wzrost udziału przemysłu przetwórczego odnotowała w tych latach jeszcze tylko Finlandia, która zwycięsko wyszła z kryzysu wywołanego załamaniem się jej ważnego partnera handlowego, mianowicie Związku Sowieckiego. Później zaś udział szwedzkiego przemysłu przetwórczego w PKB zmniejszał się, lecz w tempie podobnym lub nawet niższym niż w innych porównywalnych gospodarkach europejskich.

Zmniejszenie obciążeń podatkowych i wydatków publicznych, w połączeniu $\mathrm{z}$ deregulacją, przyniosło pozytywne efekty także w postaci przyspieszenia dynamiki wydajności pracy. Z raportu firmy konsultingowej McKinsey wynika, że wzrost ten wyniósł w sektorze przedsiębiorstw w latach 1992-2004 średnio 3,3\% rocznie. Dawało to Szwecji piąte miejsce wśród krajów OECD, za Korea Południową, Polska, Irlandia i Finlandią ${ }^{16}$. Konkurencyjność szwedzkiego biznesu wyraźnie więc się poprawiła po kryzysie i zmianach modelowych, które ten kryzys spowodował. Jednak tempo wzrostu wydajności w całej gospodarce wyniosło w tymże okresie już tylko $2,4 \%$ rocznie.

Szwedzką wydajność ciągnie w dół sektor publiczny. Mimo bardzo znacznych cięć wydatków publicznych w ocenianym okresie 1992-2004, które łącznie wyniosły 17,2 punktu procentowego PKB(!), sektor publiczny ciagle jeszcze był ponadprzeciętnie duży nawet wśród krajów europejskiego modelu socjalnego. Przeciętne zatrudnienie $\mathrm{w}$ sektorze publicznym nadal było proporcjonalnie prawie dwa razy wyższe niż $\mathrm{w}$ innych rozwiniętych krajach europejskich. Nawet w okrojonym modelu 2.0, mimo znacznych cięć udziału sektora publicznego w PKB i zatrudnieniu, nadal stanowił on czynnik ciagnący w dół dynamikę szwedzkiej gospodarki.

Największe pozytywne zmiany, choć trudno kwantyfikowalne, nastąiły w obszarze powiększania zakresu i skali wolności nie tylko ekonomicznych. Jak pisał cytowany już wcześniej Mauricio Rojas, syn lewicowych chilijskich emigrantów, którzy znaleźli się w Szwecji po upadku rządów prezydenta Allende, trudno było sobie wyobrazić w latach 70. i 80. XX w. jakiekolwiek prawa mieszkańca Szwecji do wyboru szkoły czy lekarza. Człowiek był przypisany do określonej szkoły (przedszkola też!) czy też do określonego ośrodka zdrowia w zależności od miejsca zamieszkania. Wszyscy świadczeniodawcy byli przy tym państwowi.

${ }^{16}$ McKinsey Global Institute, Sweden's Economic Performance: Recent Development, Current Priorities. Synthesis, May 2006. 
To podejście zmieniło się radykalnie. Szwecja po kryzysie stała się państwem o wysokim stopniu wolności nie tylko ekonomicznych, lecz także obywatelskich. Pojawiły się rozmaite szkoły niepaństwowe: szkoły niezależne (zakładane np. przez rozmaite fundacje) czy najzwyklejsze szkoły prywatne, a nawet sieci szkół znajdujących się w rękach jednej firmy. W połowie poprzedniej dekady takich szkół było ponad 700 .

Ale nie jest to jeszcze nic nadzwyczajnego. U nas także po upadku systemu komunistycznego zaczął się taki sam proces, nawet znacznie bardziej dynamiczny. To, co wyróżnia Szwecję w ramach modelu 2.0, to wprowadzony jeszcze w latach 90. ubiegłego wieku school voucher (czek szkolny). Rodzice każdego dziecka $\mathrm{w}$ wieku szkolnym otrzymuja taki czek i z tym czekiem mogą udać się do każdej szkoły, państwowej lub niepaństwowej, i tam zapisać do niej swoje dziecko. Tak więc w modelu szwedzkim 2.0 udało się zrealizować zasadę swobody wyboru, której mimo pozytywnych wyników eksperymentów $\mathrm{z}$ czekiem szkolnym $\mathrm{w}$ kilku stanach USA nie udało się przeprowadzić w skali całego kraju.

Podobne zmiany w sensie wolności wyboru lekarza nastąpiły i w ochronie zdrowia. Tam także zawitał sektor prywatny. Ba, zawitał także do systemu zabezpieczenia społecznego. Zmiany $\mathrm{w}$ systemie emerytalnym oddały do dyspozycji każdego pracującego 2,5 punktu procentowego jego/jej płacy brutto. Każdy pracujacy jest zobowiązany do inwestowania tych pieniędzy w celu tworzenia funduszu, z którego czerpać będzie uzupełniające środki po przejściu na emeryturę. Co ważniejsze, w ramach liberalizacji systemu nie stworzono żadnych państwowych czy pozostających pod szczególnym państwowym nadzorem funduszy emerytalnych, lecz dano każdemu możliwość inwestowania $\mathrm{w}$ istniejących prywatnych instytucjach finansowych.

\section{CZY MODEL SZWEDZKI JESZCZE JEST SZWEDZKI I CZY OSIĄGNIĘCIA SZWECJI SA OSIĄGNIĘCIAMI ORYGINALNEGO MODELU SZWEDZKIEGO?}

Zacznę podsumowanie eksploracji modelu szwedzkiego i jego przemian od odpowiedzi na pierwsze $\mathrm{z}$ dwóch postawionych $\mathrm{w}$ powyższym tytule pytań. Obraz, jaki wyłania się z mojej analizy, w zasadzie prowadzi do postawienia tezy o zwyczajności dzisiejszej Szwecji jako wysoko rozwiniętej gospodarki kapitalistycznej z przerośniętym udziałem wydatków publicznych ( $\mathrm{w}$ tym zwłaszcza państwa socjalnego). Zacznijmy od wysokiego udziału wydatków publicznych (w tym wydatków na socjal) w PKB.

Pod tym względem Szwecja z jej udziałem wydatków publicznych po $2000 \mathrm{r}$. mogłaby być równie dobrze (czy może raczej równie źle?) Austrią, Belgia, Finlandią czy też Francją lub Włochami. We wszystkich tych krajach udział wydatków publicznych przekraczał z reguły w XXI w. połowę PKB. W każdym $\mathrm{z}$ tych krajów, $\mathrm{z}$ reguły z coraz większym trudem, udawało się też finansować wszystko ogarniające programy tego, co nazywa się często w literaturze „europejski model socjalny”. I w każdym z nich dokonywano takich czy 
innych koniecznych cięć, gdy budżet przestawał się domykać, a możliwości zadłużania się kurczyły.

Czyli z punktu widzenia jakiejś odrębności modelu państwa opiekuńczego choćby pod względem skali socjalu - Szwecja po kryzysie pierwszej połowy lat 90. ubiegłego wieku przestała prezentować sobą odrębny model. Model szwedzki państwa socjalnego przestał istnieć po kryzysie. Można powiedzieć, że model szwedzki to było tylko to, co nazywam w tym artykule modelem szwedzkim 1.0. Model szwedzki 2.0, opisywany w części IV artykułu, jest $\mathrm{w}$ gruncie rzeczy jednym z przypadków ogólniejszego europejskiego modelu socjalnego.

Warto podkreślić w tym miejscu szczególne znaczenie procesów rozwojowych gospodarki szwedzkiej, a zwłaszcza wysoce konkurencyjnego w świecie szwedzkiego przemysłu przed wprowadzeniem modelu szwedzkiego 1.0. Przypomnę, że w latach 1860-1910 gospodarka szwedzka rejestrowała najszybszy wzrost PKB ze wszystkich istniejących wówczas krajów świata. Ta pozycja lidera wzrostu gospodarczego prawie się nie zmieniła w trudniejszym okresie 1910-1950. Po zakończeniu II wojny światowej Szwecja miała PKB per capita dwa razy wyższy od średniej (zachodnio)europejskiej i była czwarta gospodarką świata pod względem tegoż miernika. Pozycję europejskiego lidera pod względem PKB per capita zachowała jeszcze w 1970 r. Przemysł szwedzki, rozbudowany jeszcze bardziej w czasie II wojny światowej, był wysoce konkurencyjny w świecie.

Nie ulega wątpliwości, że ekspansja państwa socjalnego i sektora publicznego w niespotykanej gdzie indziej skali nie byłaby możliwa i nie trwałaby aż trzy dekady, gdyby nie dynamizm i efektywność szwedzkiej gospodarki, odziedziczone przez model szwedzki po liberalnej gospodarce Szwecji w poprzedzającym stuleciu. W przeciętnie szybko rozwijającej się gospodarce zachodnioeuropejskiej taka skala ekspansji socjalu zakończyłaby się podobną katastrofa - tyle że znacznie wcześniej...

Przenieśmy z kolei punkt ciężkości rozważań z państwa socjalnego na państwo niańkę. Tutaj zakres uniformizacji i jednoczesnego upaństwowienia usług (od przedszkoli zaczynając...) w czasach folkhemmet wyróżniał Szwecję spośród zamożnych państw zachodnioeuropejskich. Później już zdecydowanie ni e. Po zmianach, jakie zaczęły się w pierwszej połowie lat 90 ., Szwecję nie tylko można traktować jako typowa zachodnią demokrację oferująca swoim obywatelom duży zakres wolności wyboru także w systemie opieki społecznej, lecz także jako kraj skłonny do eksperymentów liberalnych.

Czek szkolny, o który w końcu XX w. i jeszcze w czasie pierwszej kadencji prezydentury George'a W. Busha toczono polityczne boje w USA, w Szwecji przeszedł niemal bezkonfliktowo. Zaczątki własnej troski pracujących o ich przyszłe emerytury nie są może imponujące w wymiarze absolutnym: 2,5\% płacy brutto do indywidualnego inwestowania. Ale biorąc pod uwagę to, że poza światem anglosaskim trudno znaleźć na Zachodzie kraje, które zrobiły cokolwiek, wychodząc poza system repartycyjny (pay-as-you-go), nawet ów szwedzki eksperyment przyjąć trzeba pozytywnie.

Gdybym chciał być złośliwy, to napisałbym, że duch postępu kolektywistycznego modelu szwedzkiej socjaldemokracji unosi się już tylko nad mediami i w ogóle debata publiczną. Rozmaite socjalistyczne utopie plus 
niezwykle wysoki poziom politycznej poprawności nadal dominuja w dysku$\operatorname{sjach}^{17}$.

Przechodząc do drugiego pytania, trudno byłoby znaleźć w osiagnięciach Szwecji takie, które można by zapisać na rachunek szwedzkiego modelu (tego oryginalnego, nazwanego przeze mnie modelem 1.0). Oczywiście, jest rzeczą możliwą, że ci, którzy mierza postęp społeczny według kryterium: im więcej, tym lepiej, wielbiciele socjalu $\mathrm{w}$ największych ilościach, będą $\mathrm{z}$ nostalgia powracać do lat 60.-80. XX w., kiedy to udział wydatków publicznych w PKB więcej niż podwoił się: z 31,4\% w 1964 r. do prawie $70 \%$ w przededniu kryzysu.

Jako ekonomista nie mogę jednak uznać tego za sukces. Zachowanie rządzących w tym okresie przypomina bardziej utracjusza, który wydaje więcej i więcej, nie tylko nic nie oszczędzając z bieżących dochodów, lecz także sięgając jeszcze do oszczędności, aby w którymś momencie zobaczyć przysłowiowe dno szkatuły. Owym dnem szkatuły była, oczywiście, zdolność do rozwoju szwedzkiej gospodarki. Im bardziej instytucje tejże gospodarki oddalały się od liberalnego modelu, tym mniej dynamizmu wykazywała szwedzka gospodarka czasów modelu szwedzkiego (tego 1.0!). Kiedy okazało się, że wzrost gospodarczy słabnie, a jednocześnie nie jest możliwe dalsze podnoszenie podatków, trzeba było szybko - pod groźbą bankructwa - ciąć wydatki publiczne. I te cięcia zmniejszyły udział wydatków publicznych z ponad $70 \%$ w początkach lat 90 . XX w. do nieco ponad 50\%. W żadnym kraju OECD udział ten nie został ścięty w tak wielkiej skali. Oczywiście skala cięć odpowiadała skali wcześniejszych ekscesów - niefrasobliwego zwiększania tychże wydatków w nieskończoność.

Zwolennicy egalitaryzmu mogą z kolei uznać za wielkie osiagnnięcie szwedzkiego modelu wyrównywanie poziomu płac (do dziś te różnice są w Szwecji najmniejsze spośród krajów OECD - zob. tabela 2). Oceniam jednak model szwedzki przede wszystkim z ekonomicznego punktu widzenia. A z tej perspektywy przejście od zasady równej płacy za równą pracę do zasady równości płac niezależnie od pracy musiało oddziaływać antyefektywnościowo. I tak też oddziaływało i oddziałuje do tej pory. Konsensusowi szwedzkiemu co do rozwiniętego państwa socjalnego w ramach modelu dobrego domu (folkhemmet) odpowiadać powinien konsensus Szwedów, co do solidnej pracy każdego zatrudnionego. $\mathrm{Z}$ czasem jednakże pojawiać się zaczęły znane problemy słabnących bodźców, mianowicie jazda na gapę.

$\mathrm{Z}$ jednej strony pojawiła się skłonność do uciekania w szarą strefę. Nie powinno być zaskoczeniem, że wysokie wydatki i podatki maja wpływ na wielkość szarej strefy. Dlatego po krajach południa Europy (Włochy, Hiszpania) następną grupa krajów z wysokim udziale szarej strefy były w przeprowadzonych badaniach porównawczych kraje skandynawskie (Szwecja, Norwegia i Dania) ${ }^{18}$.

Szczególnie szwedzkim problemem jednak pozostaje inny rodzaj jazdy na gapę, a mianowicie wysoka absencja w pracy. Trudno ją uznać w całości za absencję chorobową, gdyż poziom tej absencji wyraźnie rósł lub malał

17 Zob. np. J. Kubitsky, Alfabet szwedzki, Difin, Warszawa 2011.

${ }^{18}$ Black Hole, ,The Economist” z 28 sierpnia 1999 r. 
w zależności od regulacji ustalających poziom rekompensaty za nieobecność w pracy. W warunkach wysokiej rekompensaty (równej 100\% dniówki roboczej), absencja rosła niepowstrzymanie przez lata 70. i 80. XX w., dochodząc do 9,7\% w przededniu kryzysu (w 1988 r.). Kryzys i reformy ówczesnej konserwatywno-liberalnej koalicji spowodowały, że do 1997 r. absencja zmalała do 3,8\% (prawdopodobnie rzeczywistego poziomu absencji chorobowej). „Postępowe" zmiany w stawkach, wprowadzone przez zwycięskich socjaldemokratów spowodowały jednak kolejny, z roku na rok rosnący wzrost absencji. Do dziś wymienia się ja jako jeden z problemów szwedzkiej gospodarki ${ }^{19}$. O płacowym modelu szwedzkim można powiedzieć w tym względzie, że doprowadził do erozji tradycyjnego w Szwecji konsensusu w sprawie solidnej pracy.

Dostosowania do braku zróżnicowania płacowego nie dotyczą tylko tych, którzy wybierają jazdę na gapę. Również ci, którzy chcieliby dobrze pracować, ale też i odpowiednio dobrze zarabiać, dostosowują się na swój sposób. Otóż na przykład co czwarty szwedzki inżynier po ukończeniu studiów wyjeżdża za granicę. Bodźce do emigracji są w dodatku jeszcze silniejsze, gdyż - jak o tym wzmiankowałem - realne płace netto po opodatkowaniu nie rosną w Szwecji już od połowy lat 70. XX w. Egalitaryzm płacowy pozbawia ten kraj wielu zdolnych, wykształconych i pracowitych ludzi. Innym sposobem adaptacji jest przenoszenie siedziby firmy po połączeniu firmy szwedzkiej z zagraniczna do innego kraju. Od lat 80. XX w. żadna fuzja międzynarodowa nie spowodowała ulokowania siedziby głównej połączonej firmy na terenie Szwecji!

Nie ulega watpliwości, że płacowy model szwedzki w połączeniu z silnym wzrostem świadczeń socjalnych (i nieuchronnie podatków) były czynnikiem osłabiającym efektywność gospodarki i próby zwiększenia poziomu konkurencyjności szwedzkiego przemysłu podejmowane od czasu kryzysu zderzają się $\mathrm{z}$ owymi barierami po dziś dzień. W ciągu ostatnich dwadziestu lat osiągnięto w wyniku reform częściowe sukcesy. Nadal jednak pozostaje wiele nierozwiązanych problemów, będących spadkiem po modelu szwedzkim - nie tylko problemów płacowych zresztą.

W części schedą po modelu szwedzkim jest także stosunkowo niski poziom przedsiębiorczości gospodarki szwedzkiej. Jacob Arfwedson i Johnny Munkhammar zwracali nie tak dawno uwagę na fakt, że tylko jedna z 50 największych szwedzkich firm została założona po $1970 \mathrm{r} .{ }^{20}$ Tę powolność zmian w Szwecji porównać można z regularną wymianą mniej więcej połowy największych amerykańskich firm w okresie dekady na liście pięciuset, publikowanej corocznie przez „Forbesa”.

Moim zdaniem związek z modelem szwedzkim bierze się z tego, że państwo, które opiekuje się obywatelem od kołyski po grób, oddziałuje negatywnie na skłonność do oszczędzania. Przecież znaną receptą na przedsiębiorczość jest połączenie dobrego pomysłu na firmę z własnymi oszczędnościami autorów pomysłu i rozpoczęcie pracy nad pomysłem (zwykle w garażu). Tymczasem

\footnotetext{
${ }^{19}$ McKinsey Global Institute, op. cit.

${ }^{20}$ J. Arfwedson, J. Munkhammar, Searching for a Swedish Model, „Wall Street Journal” z 25 maja 2005 r.
} 
w latach 1970-1989 poziom oszczędności netto gospodarstw domowych był bardzo niski i spadał często poniżej zera; Szwedzi więcej pożyczali, niż oszczędzali. Z drugiej strony, w warunkach bardzo wysokich i rosnących podatków Szwedzi mogli nawet być skłonni do oszczędzania, ale nie mieć dostatecznych możliwości w tym względzie.

Wzmiankowani J. Arfwedson i J. Munkhammar konkludowali w 2005 r., że „,Szwecja żyje z sukcesów swej przeszłości” ${ }^{21}$. Sprawa wydaje się jednak bardziej złożona. Ciężki kryzys pierwszej połowy lat 90. nauczył bowiem Szwedów pewnej przezorności. Oszczędności gospodarstw domowych netto pozostają cały czas dodatnie, a od $2001 \mathrm{r}$. utrzymują się na przyzwoitym poziomie między $7 \%$ i $12 \%$. Natomiast poziom przedsiębiorczości, mierzony liczbą nowo zakładanych firm, nadal jest przeciętny. W najlepszym razie utrzymuje się na przeciętnym dość niskim zreszta - poziomie zachodnioeuropejskim. Wskazują na to statystyki w tabeli 4.

Tabela 4

Poziom przedsiębiorczości w wybranych krajach OECD

(mierzony wskaźnikiem nowej przedsiębiorczości) $a$

\begin{tabular}{|l|c|c|c|c|c|c|}
\hline \multicolumn{1}{|c|}{ Kraj } & $\mathbf{2 0 0 0}$ & $\mathbf{2 0 0 2}$ & $\mathbf{2 0 0 4}$ & $\mathbf{2 0 0 7}$ & $\mathbf{2 0 0 9}$ & $\mathbf{2 0 1 1}$ \\
\hline Szwecja & 6,7 & 4,0 & 3,7 & 4,2 & $\ldots$ & 5,8 \\
Belgia & 4,8 & 3,0 & 3,5 & 3,2 & 3,5 & 5,7 \\
Dania & 7,2 & 6,5 & 5,3 & 5,4 & 3,6 & 4,6 \\
Finlandia & 8,1 & 4,6 & 4,4 & 6,9 & 5,2 & 6,3 \\
Francja & 5,6 & 3,2 & 6,0 & 3,2 & 4,3 & 5,7 \\
Niemcy & 7,5 & 5,2 & 4,5 & $\ldots$ & 4,1 & 5,6 \\
Włochy & 7,3 & 5,9 & 4,3 & 5,0 & 3,7 & $\ldots$ \\
Memorandum: & & & & & & \\
Czechy & & & & & & 7,6 \\
Polska & 10,0 & 4,4 & 8,8 & $\ldots$ & $\ldots$ & 9,0 \\
Węgry & 11,4 & 6,6 & 4,3 & 6,9 & 9,1 & 6,3 \\
\hline
\end{tabular}

$a$ - Firmy w procesie rejestracji i firmy powstałe w minionych 42 miesiącach: liczba firm na 100 mieszkańców

Źródła: Global Entrepreneurship Monitor, 2004, 2007, 2009 i 2011.

Cechą charakterystyczną Szwedów jest ich skłonność do działań grupowych. Wprawdzie podręczniki zarządzania wysoko oceniają takie skłonności, ale gdy przychodzi do osiągnięć o charakterze innowacyjnym, indywidualizm potrzebuje przestrzeni (także zarządczej) do ekspansji. Tymczasem $\mathrm{z}$ racji ich historycznych korzeni, jak podejrzewam, z tym indywidualizmem nie jest u Szwedów najlepiej.

Już w kwestii przyczyn mało dynamicznego rozwoju przedsiębiorczości niedawny raport GEM (Global Entrepreneurship Monitor) zwraca uwagę na

${ }^{21}$ Ibidem. Zob. także N. Sanandaji, The Swedish Model Reassessed, Libera, Helsinki, October 2011. 
interesująca sprzeczność. Mianowicie Szwedzi postrzegaja istnienie korzyści z założenia i prowadzenia własnej firmy, ale bardzo niewielu podejmuje taka próbę. Siebie zaś częściej widzą być może w roli innowatorów, ale w dużej firmie, w wyodrębnionej grupie (intrapreneurship) ${ }^{22}$.

Jest jeszcze jedna zagadka, która też - jak się zdaje - wiąże się z konfliktem między innowacyjnością a preferencjami dla działań grupowych. Otóż Szwecja od prawie dwóch dziesięcioleci jest światowym liderem wydatków na badania i rozwój $(B+R)$; oscylują one od lat na poziomie około $4 \%$ PKB. Tyle że stopa zwrotu od tych inwestycji w kapitał ludzki wydaje się mierna.

Po pierwsze, z badań Leszka Zienkowskiego wynikało, że przy znacznie wyższym poziomie wydatków mierzonych $\mathrm{w}$ tysiącach USD Szwecja wydawała per capita $01 / 3$ więcej pieniędzy na $\mathrm{B}+\mathrm{R}$ niż na przykład Niemcy czy Francja, o połowę więcej niż Wielka Brytania, dwa razy więcej niż Włochy, a wszystkie te kraje miały ten sam mniej więcej poziom PKB na mieszkańca ${ }^{23}$.

Po drugie, analitycy zwracają uwagę, że Szwecja ma wielkie trudności nie tylko $\mathrm{z}$ tworzeniem i sukcesem nowych firm, lecz także $\mathrm{z}$ tworzeniem tych firm w nowoczesnych branżach gospodarki, charakteryzujących się wysoką intensywnością wykorzystania kapitału ludzkiego. Cytowałem już opinię prof. Eklunda z lat 90. XX w., który zwracał uwagę na to, że Szwecja konkuruje od lat w branżach o średnim i niskim poziomie intensywności technologicznej, w których konkurencja jest coraz trudniejsza w warunkach tak wysokich kosztów pracy, jakimi obciążone sa firmy szwedzkie. Od tamtych czasów odnotowano umiarkowany postęp, ale problemy pozostają. Przykładem są od kilku lat dwie perły w koronie szwedzkiego przemysłu, które niezdolne do samodzielnego konkurowania zmieniły już 2-3 razy zewnętrznego właściciela; mam na myśli producentów samochodów osobowych: Volvo i Saaba.

Podsumowując więc ocenę tego, czy model szwedzki wniósł jakiśs ( $w$ domyśle: pozytywny) wkład w rozwój szwedzkiej gospodarki, odpowiedź jest negatywna. Nie bardzo widać owe korzyści, natomiast niezamierzone negatywne następstwa modelu szwedzkiego kładą się ciężarem na dynamizmie szwedzkiej gospodarki.

Warto dodać, że często podkreślane przez apologetów ekonomiczne i pozaekonomiczne korzyści szwedzkiego modelu 1.0, czyli owego kolektywistycznego folkhemment, bynajmniej nie muszą być następstwem owego modelu, lecz raczej wspomnianej na wstępie historycznej ewolucji instytucjonalnej i ukształtowanych w tym procesie cech homo Svedensis. Doskonałą ilustracją tej ogólnej tezy jest historia przytoczona przez Nima Sanandaji, autora cytowanego już raportu na temat modelu szwedzkiego ${ }^{24}$. Otóż pewien szwedzki ekonomista lewicowej proweniencji intelektualnej stwierdził $\mathrm{w}$ rozmowie $\mathrm{z}$ Miltonem Friedmanem, laureatem nagrody Nobla z ekonomii, że my w Skandynawii nie mamy biedy. Na to Friedman, znany ze swoich szybkich i ciętych ripost, odpowiedział: „To ciekawe, ponieważ w Ameryce też nie ma biedy wśród Amerykanów skandynawskiego pochodzenia".

\footnotetext{
22 Zob. GEM, Sweden 2012 Report, 19 June 2012.

${ }^{23}$ L. Zienkowski, Wiedza a wzrost gospodarczy, Scholar, Warszawa 2003.

${ }^{24}$ N. Sanandaji, op. cit., s. 24.
} 
Wzmiankowany autor podaje wyniki badań poziomu biedy, z których wynika, że w Szwecji, według amerykańskich standardów oceny, do biednych zalicza się zaledwie 6,7\% mieszkańców kraju. Tylko w USA Amerykanie szwedzkiego pochodzenia również mają wskaźnik osób biednych rzędu 6,7\%! Dla odmiany średni PKB na Szweda w Szwecji wynosił w tym czasie (2008 r.) $\$ 36600$, a na Amerykanina szwedzkiego pochodzenia $\$ 56900$, a więc w warunkach większej wolności ekonomicznej Szwedzi pracują znacznie efektywniej.

Prowadzi to doktora Sanandajiego do stwierdzenia, że sukcesy gospodarki szwedzkiej zależały i zależą od szwedzkiej kultury, w tym etyki protestanckiej, a nie od socjaldemokratycznego modelu państwa. Autor niniejszego artykułu formułuje podobny pogląd - tyle że w innych kategoriach. Sukcesy ekonomiczne, a także pozaekonomiczne (np. w radykalnym zmniejszeniu biedy), zależą przede wszystkim od historycznie ukształtowanych instytucji.

dr hab. Jan Winiecki

Profesor Wyższej Szkoty Zarzadzania i Informatyki w Rzeszowie

\section{EVOLUTION OF THE SWEDISH ECONOMIC MODEL}

\section{Summary}

The author looks at the emergence and evolution of the Swedish economic model (called herein: model 1.0) and confronts it with the performance of the economy. He stresses a particular feature of the Swedish history, namely the relation between the king and the peasantry, as the precondition for a successful introduction of the collectivist folkhemmet model, based on a large public (social) sector and egalitarian wages and income policies.

This model was pursued determinedly (despite the slowly deteriorating performance of the economy) until the acute crisis of the early 1990s. Under its impact the model has been cut in size (from approx. 70\% GDP to 50\% GDP now) and modified in terms of access to various benefits (in order to reduce 'free riding'). The modified model, called here: model 2.0, has few characteristics of the model 1.0 and is barely distinguishable from the more general European social model.

The author evaluates the impact of the Swedish model (1.0) on the performance of the economy in negative terms. Partial evidence is supplied by improved performance after the crisis-generated reforms, with a faster growth of labour productivity, and greater international competitiveness of the Swedish manufacturing in the post mid-1990s period. These were spurred by the cuts in public expenditures and taxes (and resulting stronger incentives for individuals), as well as enhanced economic and civic freedoms.

However, even the modified model 2.0 is still hobbled by the egalitarian wage structure, low R\&D efficiency, with the resultant inability of the economy to create private sector jobs. Altogether, the author's opinion is that whatever positive effects have been registered by the Swedish economic performance, they resulted from the impact of the history-shaped institutions (including the protestant ethics) and earlier successes of the liberal Swedish economy, which in the period of 1860-1950 grew the fastest in the world, preceding the expansion of the collectivist Swedish model. 